\title{
Impaired non-specific delayed cutaneous hypersensitivity in bird fancier's lung
}

\author{
RAMON ORRIOLS, FERRAN MORELL, VICTOR CURULL, ANTONIO ROMAN, \\ GABRIEL SAMPOL
}

From the Section of Pneumology, Hospital General Vall d'Hebron, Barcelona, Spain

ABSTRACT The relation between non-specific delayed cutaneous hypersensitivity and bird fancier's $\frac{?}{\omega}$ lung was investigated in 13 patients with the disorder. They were compared with 50 subjects who had no reason to have decreased non-specific delayed cutaneous hypersensitivity (control group) and 34 을 patients with pulmonary sarcoidosis. In addition, 13 patients with bird fancier's lung (11 of the $\overrightarrow{T 1}$ original group) were tested at least one year after avoiding exposure to the causal antigen. Five $\underset{O}{\mathbb{D}}$ antigens (candidine, staphylococcal toxoid, tuberculin purified protein derivative, trichophyton, and streptokinase-streptodornase) were injected intradermally $(0 \cdot 1 \mathrm{ml})$ and the mean weal diameter was $<$ measured at 48 hours. The mean weal size was significantly less in the subjects with bird fancier's lung $\vec{\oplus}$ at the time of diagnosis than in the control group $(2.23 v 5.66 \mathrm{~mm})$ but did not differ significantly from ${ }^{\infty}$ that of the subjects with sarcoidosis $(2.80 \mathrm{~mm})$ or from that of the bird fanciers with no exposure to the causal antigen for one year $(2.75 \mathrm{~mm})$. The impairment of non-specific delayed cutaneous hypersensitivity in patients with bird fancier's lung appears to be quantitatively similar to that occurring in sarcoidosis.

\section{Introduction}

Antigenic products induce a delayed reaction when injected into the skin of previously sensitised individuals. These cutaneous tests of delayed hypersensitivity are used to assess the immune cellular response in clinical practice. Under some circumstances, however, such reactivity may be decreased or non-existent. ${ }^{2}$ Extrinsic allergic alveolitis (hypersensitivity pneumonitis) comprises a group of granulomatous disorders related to the inhalation of organic substances. ${ }^{3}$ The clinical features ${ }^{4-6}$ and histopathological characteristics ${ }^{7}$ are well documented. Studies of delayed cutaneous hypersensitivity to specific antigens have been carried out in patients with extrinsic allergic alveolitis to define the possible diagnostic value of the antigens. ${ }^{89}$ To our knowledge no systematic human studies with non-specific antigens have been carried out to determine nonspecific delayed cutaneous hypersensitivity in patients with these diseases.

Address for reprint requests: Dr Ramon Orriols, Secció de Pneumologia, Hospital General Vall d'Hebron, Pg Vall d'Hebron, s/n 08035 Barcelona, Spain.

Accepted 9 November 1988
The purpose of this study was to investigate the $\overrightarrow{\vec{O}}$ relation between non-specific delayed cutaneous hypersensitivity and bird fancier's lung, both after diagnosis and at least one year after avoidance of the causal antigen. The patients were compared with a group of patients with sarcoidosis, a granulomatous lung disease in which delayed hypersensitivity is $\underset{-}{x}$ characteristically impaired. ${ }^{10-12}$

\section{Methods}

\section{SUBJECTS}

Thirteen patients ( 11 women and two men), mean age $\frac{7}{0}$ 42 (SD 15.5) years, were studied at the time of diagnosis of bird fancier's lung. The diagnosis was $N$ based on clinical, functional, radiological, and $N$ immunological criteria. All had previously had contact with birds and a history of exertional dyspnoea and most had experienced at least one episode of dyspnoea a few hours after such contact. Chest $\stackrel{\circ}{=}$ radiographs showed a diffuse interstitial pattern in all patients. Lung function tests showed a restrictive ${ }_{+}^{+}$ pattern in eight patients, and low values for carbon $\frac{0}{0}$ monoxide transfer factor were obtained in all cases. $\overrightarrow{\mathbb{D}}$ Serum precipitins to specific antigens (bird serum or $\stackrel{\stackrel{\oplus}{\mathbb{P}}}{\sigma}$ faeces), measured by counterimmunoelectrophoresis, $\Omega$ 
were present in 12 patients. Intradermal skin tests using bird serum gave a positive immediate reaction in 11. An inhalation provocation test, using a Bird Mark 4 ventilator to nebulise $2 \mathrm{ml}$ of sterilised bird serum or faeces extract at 1:100 dilution and repeated at 1:10 in the event of a negative result, gave a positive result in 11 patients.

We studied 11 of the 13 original patients with bird fancier's lung plus another two patients (11 women and two men), mean age 45 (SD 15) years, at least one year after their exposure to birds had ceased. The two additional patients had reported dyspnoea and their chest radiographs showed a diffuse interstitial pattern. Lung function tests showed a restrictive pattern and decreased carbon monoxide transfer factor. These two patients had serum precipitins to specific antigens and positive responses to intradermal skin tests and inhalation provocation tests. Seven of the 13 patients studied previously showed improvement in the diffuse interstitial pattern on the chest radiograph and in their abnormal lung function, and the rest had become normal. All patients studied one year after avoidance of the causal antigen were symptom free at the time the cutaneous tests of delayed hypersensitivity were carried out. None of the patients with bird fancier's lung had any other conditions known to decrease nonspecific delayed cutaneous hypersensitivity. ${ }^{12}$

We also studied 34 patients with sarcoidosis (28 women and six men), mean age 43 (SD 13) years. The diagnosis of sarcoidosis was based on clinical, radiological, and immunological findings. All patients had histological proof of sarcoidosis and were evaluated at the time of diagnosis and over the same period as the patients with bird fancier's lung.

Fifty control subjects (41 women and nine men), mean age 44 (SD 14) years, were studied during an admission or outpatient visit to our centre during the same period as the patients with bird fancier's lung. Individuals with a known cause for decreased nonspecific delayed cutaneous hypersensitivity ${ }^{12}$ were excluded. None of the control patients had had contact with birds.

\section{METHODS}

The antigens extracts, their origin, and the concentrations used were: candidine-Leti Laboratories, 1:100; staphylococcal toxoid-Leti Laboratories, 1:100; tuberculin purified protein derivative (PPD)Materiales y Reactivos Laboratories, $5 \mathrm{U}$ tuberculin/ $0.01 \mathrm{ml}$; trichophyton-Leti Laboratories, 1:100; and streptokinase-streptodornase-Lederle Laboratories, $4 \mathrm{U} / 1 \mathrm{U} / 0 \cdot 1 \mathrm{ml}$. Streptokinase-streptodornase was used only during the seven days immediately following its preparation.

All studies with the five antigens were performed by one observer. The antigenic solutions $(0.1 \mathrm{ml})$ were successively injected into the skin of the inner forearm, with a separation of at least $2 \mathrm{~cm}$ between each injection point. The antigens were always injected in the same order to avoid misreadings. Longitudinal and transverse measurements of the area of induration were made 48 hours later by the ballpoint pen method. ${ }^{13}$ For each reaction we obtained the mean of the longitudinal and the transverse diameters in millimetres (quantitative evaluation). The reaction was considered positive when either of the two diameters was $5 \mathrm{~mm}$ or more (qualitative evaluation). For each antigen as well as for the total of the five the mean of the mean diameters and the percentage of positive responses were determined for all subjects in each group.

\section{STATISTICAL ANALYSIS}

Data are presented as means of mean diameters (quantitative analysis) and percentages of positive results (qualitative analysis). Student's two tailed $t$ test and the Mann-Witney $U$ test were used to assess the significance of differences in the quantitative data, and the $\chi^{2}$ test with Yates's correction when needed and Fisher's exact test for the qualitative data. $p<0.05$ was considered significant.

\section{Results}

Cutaneous reactivity to each antigen was less in the patients with bird fancier's lung at the time of diagnosis than in the control subjects. The mean weal diameter for all five antigens was 2.23 (SD 3.39) $\mathrm{mm}$ in the patients with bird fancier's lung at the time of diagnosis and $5.66(7 \cdot 17) \mathrm{mm}$ in the control group. The respective percentages of subjects in the two groups with a positive response were $26.1 \%$ and $50.8 \%$ (table 1).

There were no significant differences in cutaneous reactivity between the patients with bird fancier's lung at diagnosis and the patients with sarcoidosis in either the quantitative or the qualitative evaluation (table 1).

The cutaneous reactivity of patients with bird fancier's lung after one year without exposure to the causal antigen did not differ significantly from that seen at the time of diagnosis in either the quantitative or the qualitative evaluations (table 2).

\section{Discussion}

Extrinsic allergic alveolitis is an inflammatory granulomatous response of the lung to a wide range of inhaled organic antigens. Diagnosis is based on a history of contact with the antigen in conjunction with clinical, radiological, and lung function findings, and is usually reliable when the patient presents with acute symptoms such as chills, fever, chest tightness, non- 
Table 1 Skin weal size and percentages of subjects with a positive response to tests of non-specific delayed cutaneous hypersensitivity in control subjects and in patients with bird fancier's lung (BFL) and sarcoidosis

\begin{tabular}{|c|c|c|c|c|c|c|}
\hline Antigen & & $\begin{array}{l}\text { Control } \\
(n=50)\end{array}$ & & $\begin{array}{l}B F L \\
(n=13)\end{array}$ & & $\begin{array}{l}\text { Sarcoidosis } \\
(n=34)\end{array}$ \\
\hline $\begin{array}{l}\text { Candidine } \\
\text { Staphylococcal toxoid } \\
\text { Purified protein } \\
\text { derivative } \\
\text { Trichophyton } \\
\text { Streptokinase- } \\
\text { streptodornase }\end{array}$ & $\begin{array}{l}\text { Mean (SD) } \\
\text { No (\%) } \\
\text { Mean (SD) } \\
\text { No (\%) } \\
\text { Mean (SD) } \\
\text { No (\%) } \\
\text { Mean (SD) } \\
\text { No (\%) } \\
\text { Mean (SD) } \\
\text { No (\%) }\end{array}$ & $\begin{array}{c}6 \cdot 15(8 \cdot 82) \\
28(56) \\
0 \cdot 98(2 \cdot 10) \\
7(14) \\
7 \cdot 63(7 \cdot 44) \\
28(56) \\
4 \cdot 16(4 \cdot 53) \\
28(56) \\
9 \cdot 39(7 \cdot 75) \\
36(72)\end{array}$ & $\begin{array}{l}\mathrm{p}<0.05 \\
\mathrm{NS} \\
\mathrm{p}<0.05 \\
\mathrm{NS} \\
\mathrm{p}<0.001 \\
\mathrm{p}<0.05 \\
\mathrm{NS} \\
\mathrm{NS} \\
\mathrm{p}<0.001 \\
\mathrm{p}<0.005\end{array}$ & $\begin{array}{l}3 \cdot 46(3 \cdot 23) \\
6(46 \cdot 1) \\
0 \cdot 30(1 \cdot 10) \\
0(0) \\
2(4 \cdot 02) \\
3(23) \\
2 \cdot 84(3 \cdot 60) \\
4(30 \cdot 7) \\
2 \cdot 57(3 \cdot 79) \\
4(30 \cdot 7)\end{array}$ & $\begin{array}{l}\text { NS } \\
\text { NS } \\
\text { NS } \\
\text { NS } \\
\text { NS } \\
\text { NS } \\
\text { NS } \\
\text { NS } \\
\text { NS } \\
\text { NS }\end{array}$ & $\begin{array}{c}2 \cdot 47(2.99) \\
10(29 \cdot 4) \\
0 \cdot 47(1 \cdot 33) \\
1(2.90) \\
3.91(6.08) \\
10(29 \cdot 4) \\
2.94(3.69) \\
12(35 \cdot 2) \\
4 \cdot 23(7 \cdot 39) \\
12(35 \cdot 2)\end{array}$ \\
\hline $\begin{array}{l}\text { Mean values } \\
\text { for all antigens }\end{array}$ & $\begin{array}{l}\mathrm{a} \\
\mathrm{b}\end{array}$ & $\begin{array}{l}5 \cdot 66(7 \cdot 17) \\
127(50 \cdot 8)\end{array}$ & $\begin{array}{l}\mathrm{p}<0.001 \\
\mathrm{p}<0.001\end{array}$ & $\begin{array}{l}2 \cdot 23(3 \cdot 39) \\
17(26 \cdot 1)\end{array}$ & $\begin{array}{l}\text { NS } \\
\text { NS }\end{array}$ & $\begin{array}{l}2 \cdot 80(4 \cdot 94) \\
45(26 \cdot 4)\end{array}$ \\
\hline
\end{tabular}

Table 2 Non-specific delayed cutaneous hypersensitivity in patients with bird fancier's lung during exposure to birds and after one year without exposure

\begin{tabular}{|c|c|c|c|c|}
\hline \multirow[b]{2}{*}{ Antigens } & $\begin{array}{l}\text { Exposed } \\
(n=13)\end{array}$ & $\begin{array}{l}\text { Non-exposed } \\
(n=13)\end{array}$ & $\begin{array}{l}\text { Exposed } \\
(n=13)\end{array}$ & $\begin{array}{l}\text { Non-exposed } \\
(n=13)\end{array}$ \\
\hline & \multicolumn{2}{|c|}{ Mean $(S D)$ weal diameter $(\mathrm{mm})$} & \multicolumn{2}{|c|}{ No $(\%)$ of positive responses } \\
\hline $\begin{array}{l}\text { Candidine } \\
\text { Staphylococcal toxoid } \\
\text { Purified protein derivative } \\
\text { Trichophyton } \\
\text { Streptokinase-streptodornase }\end{array}$ & $\begin{array}{l}3.46(3.23) \\
0.30(1.10) \\
2.00(4.02) \\
2.84(3.60) \\
2.57(3.79)\end{array}$ & $\begin{array}{l}3 \cdot 15(4 \cdot 70) \\
1 \cdot 61(2 \cdot 80) \\
2 \cdot 34(5 \cdot 12) \\
1 \cdot 00(2 \cdot 51) \\
5 \cdot 65(8 \cdot 86)\end{array}$ & $\begin{array}{l}6(46) \\
0(0) \\
3(23) \\
4(30) \\
4(30)\end{array}$ & $\begin{array}{l}4(30) \\
3(23) \\
3(23) \\
2(15) \\
6(46)\end{array}$ \\
\hline Mean values for all antigens & $2 \cdot 23(3 \cdot 39)$ & $2 \cdot 75(5 \cdot 39)$ & $17(26)$ & $18(28)$ \\
\hline
\end{tabular}

All differences between exposed and non-exposed patients are non-significant.

productive cough, and dyspnoea developing typically four to eight hours after antigen exposures. ${ }^{3-7}$ The diagnosis becomes more difficult when the patient has chronic symptoms and it may be difficult to differentiate the chronic form of this disease from other disorders with similar clinical symptoms. The association between exposure and the onset of symptoms is therefore frequently unclear. ${ }^{14}$ If no other organs are affected the differentiation between extrinsic allergic alveolitis and sarcoidosis may be difficult.

The Kveim test ${ }^{15}$ and specific skin tests with causal antigens ${ }^{59}$ have been successfully used in the diagnosis of sarcoidosis and extrinsic allergic alveolitis respectively. Impaired non-specific delayed cutaneous hypersensitivity to many antigens has been found in sarcoidosis but not in extrinsic allergic alveolitis. Kobayashi et $a l^{16}$ and Schrier et al ${ }^{17}$ showed that animals with experimentally induced granulomatous pulmonary inflammation had depressed delayed type hypersensitivity reactions, as evaluated by in vitro and in vivo tests. Emanuel et $a l^{18}$ have reported that reduced delayed hypersensitivity to PPD or fungal antigens was frequently present in patients with extrinsic allergic alveolitis before the diagnosis was made. Kawai et ${ }^{19}{ }^{19}$ found that the skin response to PPD was negative in patients with extrinsic allergic alveolitis with symptoms. No study has analysed this feature systematically in man, so extrinsic allergic alveolitis is not included among the causes of anergy. ${ }^{12}$

Our results show that in patients with bird fancier's $\underset{x}{\stackrel{0}{ٍ}}$ lung, one of the most frequently diagnosed forms of $\frac{\dot{\sigma}}{0}$ extrinsic allergic alveolitis in urban environments, $\stackrel{3}{-}$. non-specific delayed cutaneous hypersensitivity was $\delta$ impaired. We consider that extrinsic allergic alveolitis should be added to the causes of anergy or decreased 을 non-specific delayed cutaneous hypersensitivity. The impairment of non-specific delayed cutaneous hypersensitivity in bird fancier's lung was as intense as that $\mathrm{N}$ seen in the patients with sarcoidosis, so the test is not $\sigma$ useful in differentiating the two diseases. Nevertheless, $N$ tests of cutaneous hypersensitivity could be useful in differentiating extrinsic allergic alveolitis from other 0 interstitial lung diseases, such as cryptogenic fibrosing alveolitis, where preservation of non-specific delayed $\frac{\varnothing}{\varnothing}$ cutaneous hypersensitivity has been found. ${ }^{20}$

Compartmentalisation of the immune response may 0 explain the impairment of non-specific delayed $\bar{D}$ cutaneous hypersensitivity seen in sarcoidosis. ${ }^{21}$ The $\stackrel{\mathbb{D}}{\circ}$ total number of lymphocytes, the proportion of $T \stackrel{\vec{D}}{\mathbb{D}}$ lymphocytes, and the ratio of OKT4 to OKT8 T cells 
are increased in bronchoalveolar lavage fluid, but decreased in peripheral blood. A substantial decrease in the absolute number of OKT4 T cells explains the decrease in the peripheral ratio of OKT4 to OKT8 cells in patients with sardoidosis. ${ }^{22}$ In extrinsic allergic alveolitis the proportion of $\mathrm{T}$ lymphocytes and their total number are increased in lavage fluid and decreased, although not always significantly, ${ }^{22}$ in peripheral blood. ${ }^{23}$ Patients with extrinsic allergic alveolitis have a decreased ratio of OKT4 to OKT8 cells in lavage fluid and in peripheral blood, due to a substantial decrease in the absolute number of OKT4 cells and a moderate increase in OKT8 cells. ${ }^{22}$ The immunological changes observed in the peripheral blood of patients with extrinsic allergic alveolitis are similar to those found in sarcoidosis. This supports the idea that in extrinsic allergic alveolitis the disorder of the immune system is compartmentalised and the localisation of the effective response to the lungs could be responsible for the cutaneous anergy associated with these diseases. Recently Salvaggio ${ }^{24}$ has suggested that anergy in extrinsic allergic alveolitis might be caused by an increased suppressor $T$ cell activity, which would reduce granuloma formation by a series of genetically determined immunoregulatory events.

Kawai et al $^{19}$ reported that in summer type hypersensitivity pneumonitis tuberculin skin reactivity changed from negative to positive when symptoms subsided, suggesting that the development of anergy coincided with clinical symptoms. The persistence of impaired non-specific delayed cutaneous hypersensitivity in the patients with bird fancier's lung in our study after one year of antigen avoidance suggests that the immune disorder continues long after antigen exposure has ceased. This is in keeping with the reduced percentage of blood $\mathrm{T}$ lymphocytes observed nine months after exposure in other types of extrinsic allergic alveolitis. ${ }^{23}$ It has been suggested that the persistence of precipitins against pigeon serum proteins might be due to immune stimulation by hen's egg proteins taken as food, ${ }^{25}$ but the reasons for the impairment of non-specific delayed cutaneous hypersensitivity and other immune changes after stopping exposure to antigen are unknown.

This paper is part of the doctoral thesis of $\operatorname{Dr} \mathbf{R}$ Orriols, Pruebas cutáneas de hipersensibilidad retardada. Estudio control. Estudio en enfermedades respiratorias (Universidad Autónoma de Barcelona, 1986).

\section{References}

1 Palmer DL, Reed WP. Delayed hypersensitivity skin testing. II-Clinical correlates and anergy. J Infect Dis 1974;130:138-43.

2 Spitler LE. Delayed hypersensitivity skin testing. In: Rose NE, Friedman H, eds. Manual of clinical immunology. 2nd ed. Washington: Harper Row, 1980:200-12.
3 Pepys J. Hypersensitivity diseases of the lungs due to fungi and other organic dusts. Basel: S Karger, 1969. (Monographs in allergy, vol 4.)

4 Salvaggio J, Karr RM. Hypersensitivity pneumonitis. Chest 1979;75:270-6.

5 Reynolds HY. Hypersensitivity pneumonitis. Clin Chest Med 1982;3:503-19.

6 Fink JN. Hypersensitivity pneumonitis. J Allergy Clin Immunol 1984;74:1-12.

7 Reyes CN, Wenzel JF, Jawton BR, Emanuel DA. The pulmonary pathology of farmer's lung disease. Chest 1982;81:142-6.

8 Morell F, Orriols R, Molina C. Usefulness of skin tests in farmer's lung. Chest 1985;87:202-5.

9 Morell F, Curull V, Orriols R. Gracia J de. Skin tests in bird breeder's disease. Thorax 1986;41:538-41.

10 James DG. Immunology of sarcoidosis. Lancet 1966;ii:633-4.

11 Sharma OP, James DG, Fox RA. A correlation of in vivo delayed type hypersensitivity with in vitro lymphocyte transformation in sarcoidosis. Chest 1971;60:15-7.

12 Mitchell DN, Scadding JG. Sarcoidosis. Am Rev Respir Dis 1974;110:774-802.

13 Sokal JE. Measurement of delayed skin test response. $N$ Engl J Med 1975;293:501-2.

14 Schlueter DP. Infiltrative lung disease hypersensitivity pneumonitis. J Allergy Clin Immunol 1982;70:50-65.

15 Israel HL. Diagnostic value of the Kveim reaction. In: Fanburg BL, ed. Sarcoidosis and other granulomatous diseases. New York: Dekker, 1983:273-86.

16 Kobayashi K, Allred C, Yoshida T. Mechanisms of suppressed cell-mediated immunity and impaired antigen-induced interleukin-2 production in granuloma bearing mice. J Immunol 1985;135:2996-3003.

17 Schrier DJ, Sternick J, Allen EM, Moore VL. Genetic basis of BCG-induced suppression of delayed hypersensitivity. Nature 1981;289:404-7.

18 Emanuel DA, Wenzel FJ, Bowerman CI, Lawton BR. Farmer's lung. Clinical, pathological and immunological study of twenty-four patients. Am J Med 1964;37:392-401.

19 Kawai T, Tamura M, Murao M. Summer-type hypersensitivity pneumonitis. A unique disease in Japan. Chest 1984;85:311-7.

20 Pierce R, Turner-Warwick M. Skin tests with tuberculin (PPD). Candida albicans and Trichophyton spp. in cryptogenic fibrosing alveolitis and asbestos related lung disease. Clin Allergy 1980;10:229-37.

21 Hudspith BN, Flint KC, James DG, Brostoff J, Johnson NMc. Lack of immune deficiency in sarcoidosis: compartmentalization of the immune response. Thorax 1987;42:250-5.

22 Costabel V, Bross KJ, Ruhle KH, Lohr GW, Matthys H Ia-like antigens on T-cells and their subpopulations in pulmonary sarcoidosis and hypersensitivity pneumonitis. Analysis of bronchoalveolar and blood lymphocytes. Am Rev Respir Dis 1985;131:337-42.

23 Flaherty DK, Surfus JE, Chemelik F, et al. Lymphocyte subpopulations in the peripheral blood in patients with farmer's lung. Am Rev Respir Dis 1976;114:1093-8.

24 Salvaggio JE. Hypersensitivity pneumonitis. J Allergy Clin Immunol 1987;79:558-71.

25 Berrens L, Verschuren M, Van Vijk AG, Guikers CLM Antibodies against hen's egg proteins in pigeon breeder's disease. Clin Allergy 1986;16:355-63. 